IMAGEN EN LA PRÁCTICA CLÍNICA

\title{
Arterias coronarias en tomografía cardíaca
}

\author{
Coronary arteries in cardiac tomography
}

\section{Claudia Medina Sierra, ${ }^{1}$ Glenda Ortiz. ${ }^{2}$}

${ }^{1}$ Médico Residente IV Año, Postgrado Radiología e Imágenes Médicas (2017-2020), Facultad de Ciencias Médicas, UNAH 2Médico Especialista en Radiología, Departamento de Ciencias Biomédicas e Imágenes, Facultad de Ciencias Médicas, UNAH; Departamento de Radiología, Instituto Hondureño de Seguridad Social; Tegucigalpa.
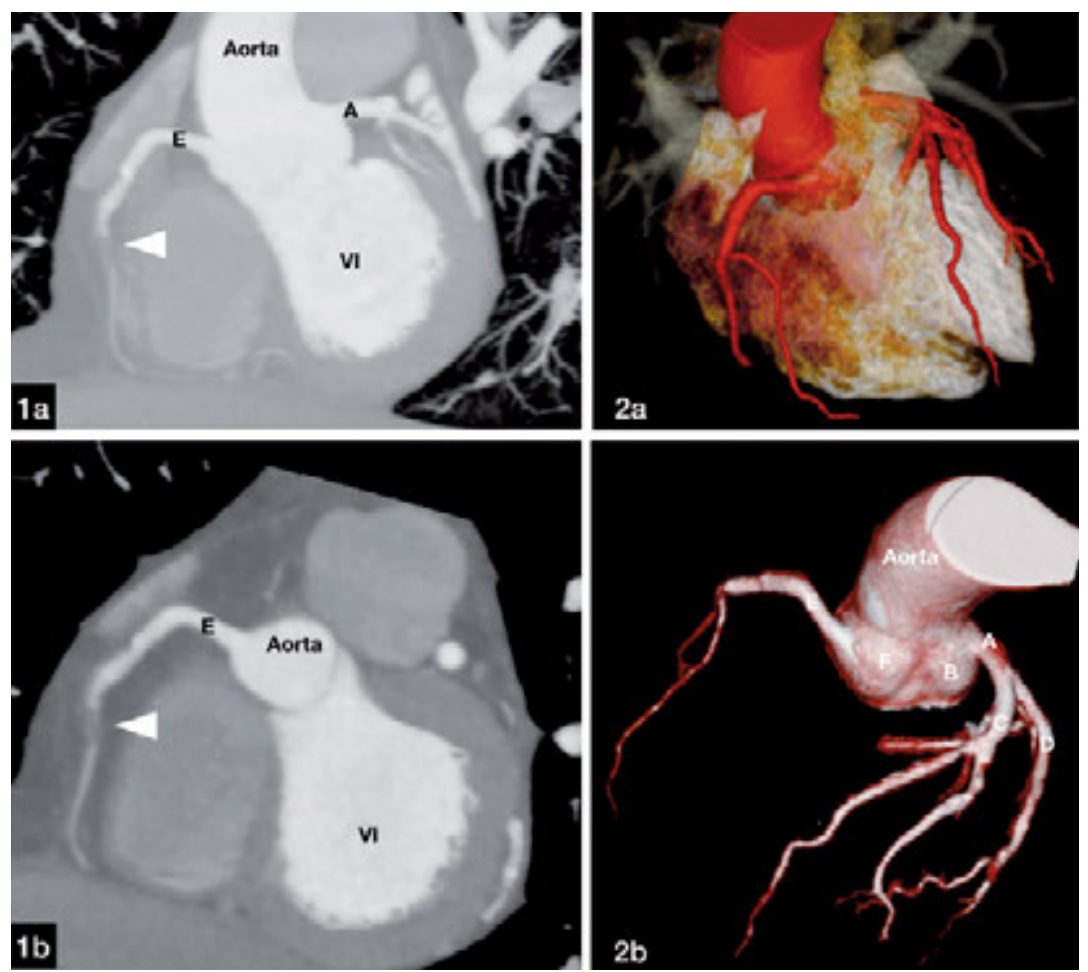

El desarrollo de equipos de tomografía axial computarizada a multicorte ha permitido el estudio de arterias coronarias de forma no invasiva, sincronizada con el electrocardiograma. El software permite la reconstrucción tridimensional del corazón y del árbol coronario, incluyendo la pared de los vasos sanguíneos, extrayendo las demás estructuras, constituyéndose en una herramienta para evaluar las estructuras cardíacas y coronarias en cualquier ángulo y proyección y su relación con las diferentes estructuras anatómicas. Se presentan imágenes en reconstrucción de Máxima Intensidad de Proyección (Fig.1a y 1b) y Volumétrica (Fig. 2a y 2b) de un paciente evaluado ambulatoriamente, demostrando arterias coronarias con origen y trayecto normal, todas con enfermedad ateromatosa. Se muestra el tracto de salida de la aorta del ventrículo izquierdo (VI) con los senos coronarios (Fig. 1a y 1b). El tronco principal izquierdo (A) nace del seno coronario izquierdo (B); en su recorrido se bifurca en arteria descendente anterior (C) y circunfleja (D). La coronaria derecha (E) se origina en el seno coronario derecho $(\mathbf{F})$, observándose una placa no calcificada, sub-oclusiva en el tercio medio de la arteria (punta de flecha). La imagen fue obtenida de la reconstrucción del tomógrafo; únicamente se modificó la identificación de las estructuras.

Recibido: 27-01-2020 Aceptado para publicación 30-06-2020

Dirección para correspondencia: Dra. Glenda Ortíz

Correo electrónico: gortiz1us@yahoo.es

Declaración de relaciones y actividades financieras y no financieras y conflictos de interés: ninguna.

DOI: https://doi.org/10.5377/rmh.v88i1.11535 